\title{
Phytochemical Profiling of Conventional and Supercritical Ginger Extract Based Baked Bars
}

\author{
Tanweer $\mathbf{S}^{1,3 *}$, Shehzad $\mathbf{A}^{1}$, Sadiq Butt $\mathbf{M}^{\mathbf{1}}$ and Shahid $\mathbf{M}^{2}$ \\ ${ }^{1}$ National Institute of Food Science and Technology, Faculty of Food, Nutrition and Home Sciences, University of Agriculture, Faisalabad, Pakistan \\ ${ }^{2}$ Department of Biochemistry, Faculty of Basic Sciences, University of Agriculture, Faisalabad, Pakistan \\ ${ }^{3}$ Bioactive Natural Product Laboratory, Plant Soil and Science Building, Michigan State University, MI, USA
}

\begin{abstract}
Contemporary, nutraceutics have attracted the consumers owing to their therapeutical potential aligned with metabolic arrays. In this ambiance, ginger is a famous herb that has the ability to mitigate various health related disorders due to its unique photochemistry with special reference to gingerol and shagoal. To evaluate the health boosting ability of ginger, product namely ginger bars were prepared by the addition of $3 \%$ ginger conventional nutraceutical (CSE) as well as $0.3 \%$ of supercritical nutraceutic (SFE). The product was observed for color tonality in the form of $L^{*}, a^{*}, b^{*}$, Chroma and Hue. The antioxidant potential of ginger bars was assessed by different antioxidant tests i.e. TPC, DPPH, Antioxidant activity, FRAP, ABTS and metal chelating ranges from $67.45 \pm 2.29$ to $112.28 \pm 3.81 \mathrm{mg} \mathrm{GAE} / 100 \mathrm{~g}$ for TPC, $8.28 \pm 0.28$ to $30.72 \pm 1.05 \%$ for DPPH, $13.27 \pm 0.45$ to 33.61 $\pm 1.14 \%$ for antioxidant activity, $22.15 \pm 0.75$ to $48.81 \pm 1.66 \mu$ mole TE/g for FRAP assay, $5.94 \pm 0.20$ to $19.05 \pm 0.65 \mu \mathrm{mole} \mathrm{TE} / \mathrm{g}$ for ABTS and for metal chelating it varied from $16.41 \pm 0.56$ to $21.22 \pm 0.72$ by the addendum of ginger extracts. Furthermore the ginger bars were marked by hedonic response in terms of color, crispiness, taste, flavor and overall acceptability.
\end{abstract}

Keywords: Designer product; Physico-chemical analysis; TPC; DPPH; FRAP; ABTS; FRAP; Antioxidant activity; Metal chelating

\section{Introduction}

Diet along with its constituents contributes improved state of health other than reduced risk of diseases to enhance the quality of life. These concepts motivated to the addition of functional foods in routine diet that are health boosting foods processed with biologically active ingredient in precise quantity having both qualitative and quantitative influence on health. Hence, in modern age these healthy foods are important source in management and prevention of chronic disorders [1].

In present era, the consumption rate of designer foods is increasing day by day because of its health benefits beyond to nutritional value along with enhanced shelf life owing to the addition of antioxidants that lowers the process of rancidity [2-4]. A few epochs ago, the trend of cereal based food product moved towards designer foods by the addendum of phytoceutics that improves the health stratum along with enhanced shelf life [2]. Innately, the marked chances resulted due to the oxidation reactions that transpire slowly during storage [3]. The food recipes that are modified by the supplementation of spices have improved stability against oxidation. These spices are more often used for oxidation stability to enhance shelf life in addition to providing flavor [5].

Baked products have been recognized as best vehicles for amalgamation of ginger, although there are positive effects on the physicochemical properties of baked products after the addition of ginger along with health benefits [6]. Baking is a complex process and results in manifold physical and biochemical effects including structure formation, taste development, color formation and synthesis of health promoting and health impairing constituents [7]. The bars are well known as a cradle of carbohydrates in food pyramid that ensures that a person is taking sufficient amount of nutrients in balance to require by the body. In formulation of bars, the ingredients provide its characteristics including color, flavor, taste, texture along with calories. Other parameters that have impact on attributes of bar are replacement of sugar and fat replacement over and above to addition of spices [8].
Incorporation of antioxidants such as bioactive ingredients in food products $v i z$., baked bars have been grown rapidly because of improved health status awareness [9]. These natural moieties also act as mold inhibitors that delay the production and growth of mold on baked products and help in improved shelf life. The other method to get the interest of consumer is to develop the formation of chemical free product by replacing undesired ingredients augmented by antioxidants and enzymes [8].

Ginger owing to be a rich source of aromatic and pleasant flavoring properties is commonly used in the preparation of baked products, condiments and curries [10]. It has strong antioxidant potential that has been verified to be effectual in lipid oxidation inhibition as well as declining the level of oxidation in baked products. Although, nutraceutics from ginger have desirable characteristics such as being natural, non-GMO food and clean label ingredient as it can be labeled as a food ingredient in the label of food product [11].

\section{Materials and Methods}

Three types of bars were prepared using best treatment of each nutraceutical $_{\text {CSE }}$ and nutraceutical ${ }_{\text {SFE }}$ as described in AACC (2000) method no. $10-50 \mathrm{D}$. The first $(\mathrm{T} 1)$ contained nutraceutical ${ }_{\mathrm{CSE}}$ whilst other (T2) enriched with nutraceutical ${ }_{\mathrm{SFE}}$ along with control (T0) for comparison purpose Table 1.

\section{Physico-chemical analysis}

The prepared bars were analyzed for the color, texture and

${ }^{*}$ Corresponding author: Tanweer S, National Institute of Food Science and Technology, Faculty of Food, Nutrition and Home Sciences, University of Agriculture Faisalabad, 38000, Pakistan, Tel: +92-3335143565; E-mail: sairatanweer1116@gmail.com

Received May 20, 2016; Accepted June 08, 2016; Published June 13, 2016

Citation: Tanweer S, Shehzad A, Sadiq Butt M, Shahid M (2016) Phytochemical Profiling of Conventional and Supercritical Ginger Extract Based Baked Bars. J Food Process Technol 7: 596. doi:10.4172/2157-7110.1000596

Copyright: (c) 2016 Tanweer S, et al. This is an open-access article distributed under the terms of the Creative Commons Attribution License, which permits unrestricted use, distribution, and reproduction in any medium, provided the original author and source are credited. 


\begin{tabular}{|c|c|}
\hline Treatments & Description \\
\hline $\mathbf{T}_{0}$ & Control \\
\hline $\mathbf{T}_{1}$ & Ginger bars with $3 \%$ nutraceutical \\
\hline $\mathbf{T}_{2}$ & Ginger bars with $0.3 \%$ nutraceutical \\
\hline
\end{tabular}

Table 1: Treatments used in product development.

antioxidant potential during the storage period. The color and texture parameters of bars were measured using the methods of Parn et al. [12].

\section{Color analysis}

The color analysis was performed by using CIE-Lab Color Meter (CIELAB SPACE, Color Tech-PCM, USA). Prior to analysis, the colorimeter was calibrated using the zero and white calibration plates, respectively. Samples were also analyzed to find out their hue and chroma values.

$$
\begin{aligned}
& \text { Chroma }\left(C^{*}\right)=\left[\left(a^{*}\right)^{2}+\left(b^{*}\right)^{2}\right]^{1 / 2} \\
& \text { Hue angle }(h)=\tan ^{-1}\left(\frac{b^{*}}{a^{*}}\right)
\end{aligned}
$$

\section{Texture analysis}

Texture analysis was performed using texture analyzer (single arm texture analyzer TA-XT Plus, Stable Micro Systems, Surrey, UK) with a load cell of $2 \mathrm{~kg}$ weight. A force versus time curve for a two-cycle compression was measured, with a disk probe of $35 \mathrm{mM}$ diameter and at a displacement speed of $10 \mathrm{mM} / \mathrm{min}$. Built in software of the texture analyzer was used for analyzing the data generated.

\section{Antioxidant potential}

Antioxidant potential of ginger bar was determined by the protocols described by Sharma and Gujral [13].

\section{Total Phenolic Content (TPC)}

Total phenolic contents (TPC) in ginger bars extract were measured using Folin-Ciocalteu method that was based on the reduction of phosphotungstic acid to phosphotungstic blue and as result absorbance increased due to rise in number of aromatic phenolic groups. For the purpose, $50 \mu \mathrm{L}$ of ginger bar extract was separately added to test tube containing $250 \mu \mathrm{L}$ of Folin-Ciocalteu's reagent, $750 \mu \mathrm{L}$ of $20 \%$ sodium carbonate solution and volume was made up to $5 \mathrm{~mL}$ with distilled water. After two hours, absorbance was measured at $765 \mathrm{~nm}$ using UV/ visible light Spectrophotometer (CECIL CE7200) against control that has all reaction reagents except sample extract. Total polyphenols was estimated and values were verbalized as gallic acid equivalent (mg gallic acid/100 g).

Total phenolic compounds of each extract in gallic acid equivalents (GAE) was calculated by following formula:

$$
\begin{aligned}
& \mathrm{C}=\mathrm{c} \times \frac{\mathrm{V}}{\mathrm{M}} \\
& \mathrm{C}=\text { Total phenolic contents }(\mathrm{mg} / \mathrm{g} \text { plant extract, in GAE) } \\
& \mathrm{c}=\text { Concentration of gallic acid }(\mathrm{mg} / \mathrm{mL}) \\
& \mathrm{V}=\text { Volume of extract }(\mathrm{mL}) \\
& \mathrm{M}=\text { Weight of ginger extract }(\mathrm{g})
\end{aligned}
$$

\section{Free Radical Scavenging Activity (DPPH assay)}

Sample solution of ginger bar extract was prepared by dissolving $0.025 \mathrm{~mL}$ of sample extract in $10 \mathrm{~mL}$ of respective solvent with $3 \mathrm{~mL}$ of freshly prepared DPPH solution in respective solvent that was mixed with $77 \mu \mathrm{L}$ sample extract. Each sample was kept in dark place for about 15 minutes at room temperature and decrease in absorbance was measured at $517 \mathrm{~nm}$ on UV/visible light spectrophotometer. Similarly, blank sample absorbance having the same amount of solvent and DPPH solution except extract was prepared and absorbance was estimated at same wavelength on UV/visible light spectrophotometer. The free radical-scavenging activity of each ginger extract can be presented as percentage reduction in DPPH due to given amount of each extract.

Reduction of absorbance $(\%)=\left[\frac{(\mathrm{AB}-\mathrm{AA})}{\mathrm{AB}}\right] \times 100$

$\mathrm{AB}=$ Absorbance of blank sample at $\mathrm{t}=0$ minute

$\mathrm{AA}=$ Absorbance of tested extract solution at $\mathrm{t}=15$ minutes

\section{Antioxidant Activity (AA)}

Antioxidant activity of ginger bar extracts was based on coupled oxidation of $\beta$-carotene as well as linoleic acid. In this method, $2 \mathrm{mg}$ of $\beta$-carotene was dissolved in $20 \mathrm{~mL}$ of chloroform. A $3 \mathrm{~mL}$ of aliquot was taken in flask containing $40 \mathrm{mg}$ linoleic acid along with $400 \mathrm{mg}$ Tween 20 and the mixture was then evaporated at $40^{\circ} \mathrm{C}$ for $10 \mathrm{~min}$ using rotary evaporator to remove chloroform. This mixture was diluted with $100 \mathrm{~mL}$ distilled water and was mixed properly by vortex mixer to prepare emulsion. $3 \mathrm{~mL}$ of $\beta$-carotene emulsion as well as 0.12 $\mathrm{mL}$ phenolic extracts were taken in test tubes and were thoroughly mixed. Afterward, test tubes were incubated at $50^{\circ} \mathrm{C}$ in a water bath for time duration of 30 minutes. Absorbance of each sample was measured at $470 \mathrm{~nm}$ on UV/visible light spectrophotometer. The degradation rate of the extracts was also calculated according to the first order kinetic reaction using following expression.

$$
\begin{aligned}
& \text { Sample degradation rate }=\operatorname{In}(\mathrm{a} / \mathrm{b}) \times 1 / \mathrm{t} \\
& \ln =\text { Natural } \log \\
& \mathrm{a}=\text { Initial absorbance on } 470 \mathrm{~nm} \text { at time zero } \\
& \mathrm{b}=\text { Absorbance on } 470 \mathrm{~nm} \text { after } 30 \mathrm{~min} \\
& \mathrm{t}=\text { Time in minutes }
\end{aligned}
$$

The antioxidant activity was expressed as percentage inhibition (\%) relative to the control by following equation.

$$
\text { AA }(\%)=\frac{\text { Degradation rate of control }- \text { Degradation rate of sample }}{\text { Degradation rate of control }} \times 100
$$

\section{Ferric Reducing Antioxidant Power (FRAP) assay}

The reducing power of ginger bar extracts was determined by measuring capability of extracts to reduce ferric tripyridyltriazine into blue colored ferrous that can be detected at $593 \mathrm{~nm}$. FRAP reagent was prepared by mixing $25 \mathrm{~mL}$ acetate buffer $(0.1 \mathrm{M}$ at $\mathrm{pH} 3.6), 2.5 \mathrm{~mL}$ TPTZ $(10 \mathrm{mM})$, and $2.5 \mathrm{~mL}$ ferric chloride $(20 \mathrm{mM})$ and was incubated at $30^{\circ} \mathrm{C}$ for 10 minutes. To determine reducing power of ginger extract immediately $1.5 \mathrm{~mL}$ of FRAP reagent was mixed with $100 \mu \mathrm{L}$ of ginger extract or standard and $100 \mu \mathrm{L}$ of distilled water. Then absorbance was taken at $593 \mathrm{~nm}$ on UV/visible light spectrophotometer. A calibration curve was drawn using trolox $(0-500 \mu \mathrm{mol} / \mathrm{mL})$ and was expressed as $\mu \mathrm{mol}$ trolox equivalent per gram of sample.

ABTS (2,2-Azino-Bis, 3-Ethylbenzothiazoline-6-Sulphonic Acid) Assay

ABTS assay is a decolorizing method, the ABTS radical was freshly 
prepared by adding $5 \mathrm{~mL}$ of a $4.9 \mathrm{mM}$ potassium persulfate solution to $5 \mathrm{~mL}$ of a $14 \mathrm{mM}$ ABTS solution and keeping the mixture in the dark for $16 \mathrm{hr}$. This solution was diluted further with respective solvent to yield an absorbance of $0.7 \pm 0.02$ at $734 \mathrm{~nm}$ and was used for antioxidant assay. The final reaction mixture $(1 \mathrm{~mL})$ comprised of $950 \mu \mathrm{L}$ of ABTS solution and $50 \mu \mathrm{L}$ of the extract or water was mixed for 30 seconds and allowed to stay for $5 \mathrm{~min}$ at ambient temperature. After the absorbance was recorded at $734 \mathrm{~nm}$ using a UV-visible spectrophotometer (Shimadzu UV-160A, Kyoto, Japan) and compared with the control ABTS solution. A calibration curve was made by making various concentration of Trolox $(780-1000 \mu \mathrm{L} / \mathrm{mL})$. ABTS radical scavenging activity was expressed as $\mu \mathrm{mol}$ trolox equivalent antioxidant capacity (TEAC) per gram of sample.

\section{Metal chelating potential}

Ferrous ions chelating activity of extracts was estimated in which ginger bar extracts $(0.1 \mathrm{~mL})$ were added to a solution of $2 \mathrm{mM} \mathrm{FeCl}_{2}$ $(0.05 \mathrm{~mL})$. The reaction was initiated by the addition of $5 \mathrm{mM}$ ferrozine $(0.1 \mathrm{~mL})$ and $2.75 \mathrm{~mL}$ of distilled water. The mixture was shaken vigorously and left at room temperature for $10 \mathrm{~min}$. The absorbance of the solution was then measured at $562 \mathrm{~nm}$. The scavenging activity was calculated as follows:

$$
\begin{aligned}
& \mathrm{MC}(\%)=\frac{\mathrm{A}_{\text {blank }}-\mathrm{A}_{\text {sample }}}{\mathrm{A}_{\text {blank }}} \times 100 \\
& \text { Where, } \\
& \mathrm{A}_{\text {blank }}=\text { absorbance of the control reaction } \\
& \mathrm{A}_{\text {sample }}=\text { absorbance in the presence of plant extract } \\
& \text { Samples were analyzed in triplicate. }
\end{aligned}
$$

\section{Hedonic response}

The resultant bars were evaluated by a trained panel of judges using 9 point hedonic scale as described by Parn et al. in 2015. Attributes to be tested on the products included various quality parameters such as that of aroma, taste, color, texture, overall acceptability, which were based on a nine point hedonic test scale.

\section{Results and Discussion}

\section{Physico-chemical analysis of bars}

The baked bars prepared by using conventional nutraceutical (3\%) and nutraceutical supercritical $(0.3 \%$ ginger extract) concentrations were analyzed for color tonality, texture and antioxidant potential to assess the impact of treatment as well as 60 days storage interval.

Color: The mark of consumer acceptance of food product is principally centered on color. The scrutiny of color tonality is mainly carried out with CIELAB (Commission International de l'Eclairage (CIE) $L *$ (lightness), $a *$ (redness), and $b *$ (yellowness)) color operating system that gives its interpretation as $L^{*}, a^{*}$ and $b^{*}$ traits where $L^{*}$ displays brightness, $a^{*}$ points greenish to reddish tonality, whilst $b^{*}$ indicates bluish to yellowish color. Values concerning $L^{*}$ values of bars are represented in Figure 1. The $\mathrm{L}^{\star}$ values for bars $\mathrm{T}_{0}$ (control), $\mathrm{T}_{1}$ (bars containing $3 \%$ ginger nutraceutical $\mathrm{CSE}_{\text {}}$ ) and $\mathrm{T}_{2}$ (bars containing $0.3 \%$ ginger nutraceutical ${ }_{\mathrm{SFE}}$ extract) were $60.21 \pm 2.05,58.08 \pm 1.97$ and $59.42 \pm 2.02$, correspondingly. During sixty days storage the $L^{*}$ value of bars gradually decreased from $61.02 \pm 2.07$ to $56.80 \pm 2.04$. The Values (Figure 1) for $\mathrm{a}^{*}$ value of $\mathrm{T}_{2}$ was maximum $7.03 \pm 0.24$ followed by $\mathrm{T}_{0}$ and $\mathrm{T}_{1}$ of bars ( $6.87 \pm 0.23$ and $3.69 \pm 0.23$, respectively). During storage, maximum decrease in $a^{*}$ value was observed in $T_{1}$

\section{Color Tonality}

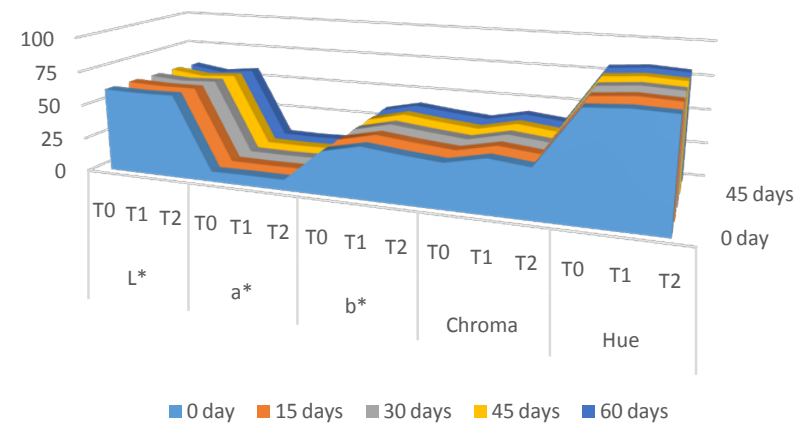

Figure 1: Color tonality of ginger bars.

ranging from $7.86 \pm 0.27$ to $5.77 \pm 0.21$. It was noticed that $\mathrm{a}^{\star}$ value of bars decreased gradually as a function of storage intervals from $7.75 \pm 0.26$ at 0 day to $6.15 \pm 0.22$ at $60^{\text {th }}$ day. According to Figure 1 it is noticeable that $b^{*}$ value increased as color of product changes to yellowish with the passage of time. As it was observed from present study that $\mathrm{b}^{*}$ value for $\mathrm{T}_{1}$ was maximum $38.68 \pm 1.32$ due to yellowish color of ginger conventional extract while minimum for $\mathrm{T}_{0}(32.42 \pm$ 1.10). Collaborative effect of treatment and storage has exposed that highest $\mathrm{b}^{*}$ value was recorded in $\mathrm{T}_{1}(37.68 \pm 1.28)$ at beginning that increased to $(39.52 \pm 1.42)$ at end of storage. However, 60 days storage has increased $b^{*}$ values from $34.65 \pm 1.18$ to $36.44 \pm 1.31$. Values in Figure 1 revealed that addition of ginger conventional extract in $T_{1}$ and ginger supercritical extract in $\mathrm{T}_{2}$ bars produced significant change in chroma value i.e. $39.25 \pm 1.34$ and $36.97 \pm 1.33$, respectively however, for $\mathrm{T}_{0}$ it was minimum $33.15 \pm 1.13$ that changed as function of time from $35.51 \pm 1.21$ to $36.96 \pm 1.33$. For hue angle, values shown in Figure 1 specified maximum value for $\mathrm{T}_{1}(80.17 \pm 2.73)$ followed by $\mathrm{T}_{2}$ and $\mathrm{T}_{0}$ (78.81 \pm 2.68 and $78.02 \pm 2.65$, consistently). Values concerning hue angle reduced during storage from $77.34 \pm 2.63$ to $80.36 \pm 2.89$. So, we can interpret that with the increase in concentration of ginger conventional extract $L^{*}$ and $a^{*}$ values decreased while $b^{*}$, chroma and hue was increased.

Color parameters: The results of current research work are comparable with the findings of Abdel-Samie et al. [14] observed the color parameters of ginger enriched cookies and suggested that $\mathrm{L}^{*}$ value of cookies was $65.3 \pm 0.6$ for control cookies prepared from wheat flour and $65.9 \pm 0.9$ to $59.9 \pm 0.2$ by the addendum of various concentration of ginger. Similarly the $\mathrm{a}^{*}$ was $8.9 \pm 0.5$ in control and changed to $7.1 \pm$ 0.2 by the addition of ginger powder. In the case of $b^{\star}$ values, it changed between $36.6 \pm 0.2$ to $37.5 \pm 0.5$ by the adjunct of ginger powder that was $38.6 \pm 0.5$ in control.

Furthermore, another group of scientists Ashoush and Gadallah, [15] prepared the biscuits by the augmentation of mango kernel peel and mango kernel powder along with control wheat flour biscuits. In their research work the color intensity of control wheat flour was 62.48 \pm 1.90 for $\mathrm{L}^{*}$ at start that decreased to $51.22 \pm 0.27$ at end of storage, 8.97 \pm 0.93 for $\mathrm{a}^{*}$ that decreased to $2.44 \pm 0.31$ while for $\mathrm{b}^{*}$ value increased from $31.64 \pm 0.39$ to $33.69 \pm 2.20$ in the end of storage interval. The chroma intensity increased from $32.90 \pm 0.43$ to $34.04 \pm 2.17$ however for hue it changes from $70.62 \pm 1.70$ to $60.00 \pm 0.39$. Similarly, Haase et al. [7] concluded that by changing baking temperature from 180 to $240^{\circ} \mathrm{C}$ the $\mathrm{L}^{*}$ values of baked products changes from $79.9 \pm 4.27$ to 72.7 \pm 4.42 . 
Citation: Tanweer S, Shehzad A, Sadiq Butt M, Shahid M (2016) Phytochemical Profiling of Conventional and Supercritical Ginger Extract Based Baked Bars. J Food Process Technol 7: 596. doi:10.4172/2157-7110.1000596

Page 4 of 7

Nonetheless, Sharma and Gujral, [13] who prepared wheat flour chapatties by the addition of barely flour. In their research work the $\mathrm{L}^{*}$ of wheat flour chapatties decreased from $84.7 \pm 0.3$ to $80.4 \pm 0.2$ whilst the $\mathrm{a}^{*}$ value decreased from $13.44 \pm 0.53$ to $12.41 \pm 0.14$ during storage. The $\mathrm{L}^{*}$ value decreased due to the production of some melanoids that decrease $L^{*}$ value however the $a^{*}$ decreased because of the product of these intermediate maillard reaction compounds that moves it towards greenish shade and bluish shade instead of yellow in the case of $b^{*}$. Although the decrease in $\mathrm{L}^{*}$ and $\mathrm{a}^{\star}$ are due to the baking in which brown pigments produced during baking [16]. Moreover, Pasqalone et al. [17] prepared the wheat flour biscuits by the enrichment of grape mac and concluded that the $\mathrm{L}^{\star}, \mathrm{a}^{*}$ and $\mathrm{b}^{\star}$ values of biscuits was $41.14 \pm$ $4.20,9.74 \pm 2.14$ and $32.18 \pm 0.40$, respectively.

Texture: Figure 2 has represented the effect of treatment as well storage on hardness of bars. It was observed that hardness for $\mathrm{T}_{1}(3 \%$ ginger conventional extract) was minimum $0.62 \pm 0.02$ in contrast to $\mathrm{T}_{2}\left(0.3 \%\right.$ ginger supercritical extract) $0.65 \pm 0.02$ and $\mathrm{T}_{0}$ (control) $0.72 \pm 0.02 \mathrm{~kg}$ force. Interactive effect of treatment as well as storage has depicted that hardness of bars containing $3 \%$ ginger conventional extract $\left(\mathrm{T}_{1}\right)$ was less effected from 0 to 60 days storage period as compared to supercritical treatment Storage of bars caused significant decrease in hardness from $0.75 \pm 0.03$ to $0.56 \pm 0.02 \mathrm{~kg}$. It is clear from the Figure 2 that the bars became soft with the passage of time due to which the force gradually decreased from $1^{\text {st }}$ day to $60^{\text {th }}$ day of storage.

The outcomes were in line with the findings of Abdel-Samie et al. [14] that prepared ginger based cookies and evaluate texture of cookies as the force required breaking it. They depicted that the force required for control cookies was $4.7 \pm 1.0 \mathrm{~kg}$ force whilst after the supplementation of ginger this force changed from $4.2 \pm 0.1$ to $3.4 \pm 0$ that was $4.7 \pm 1.0 \mathrm{~kg}$ for control cookies.

\section{Antioxidant activity of bars}

Total phenolic content: In baked products the main problem is the rancidity that reduces the attention of people. So, some attempt was employed in present research work by incorporating ginger powder and its extract in bars having bioactive moieties of ginger that were examined for their antioxidant perspective during four days storage. It is cleared from means Table 2 TPC of bars that $\mathrm{T}_{2}(0.3 \%$ ginger nutraceutical $_{\mathrm{SFE}}$ ) has maximum phenolic contents $112.28 \pm 3.81 \mathrm{mg}$ $\mathrm{GAE} / 100 \mathrm{~g}$ as compared to $\mathrm{T}_{1}\left(3 \%\right.$ ginger nutraceutical $\left._{\mathrm{CSE}}\right) 87.12 \pm 2.96$ and $\mathrm{T}_{0}$ (control) $67.45 \pm 2.29 \mathrm{mg}$ GAE/100g. During storage of bars, total phenolics gradually decreased from $92.54 \pm 3.15$ to $84.97 \pm 3.06$ $\mathrm{mg} \mathrm{GAE} / 100 \mathrm{~g}$ while minimum reduction was noted in $\mathrm{T}_{2}$ from 115.08 \pm 3.91 at 0 day to $84.97 \pm 3.06 \mathrm{mg} \mathrm{GAE} / 100 \mathrm{~g}$ at 60 days.

\section{Texture}

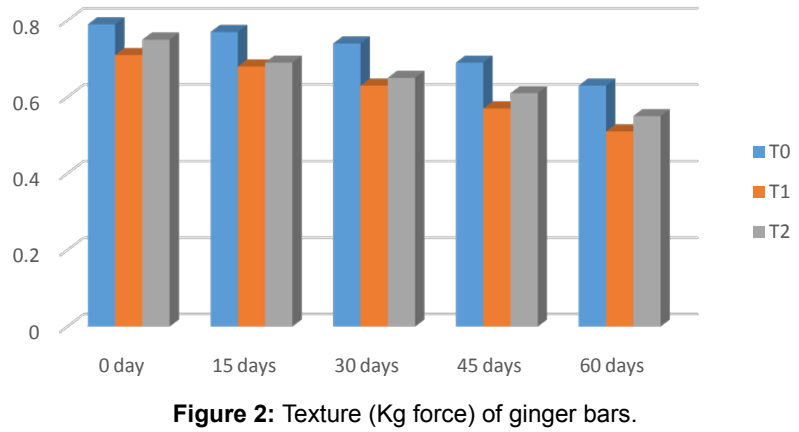

\begin{tabular}{|c|c|c|c|c|}
\hline \multirow{2}{*}{$\begin{array}{c}\text { Storage } \\
\text { intervals (days) }\end{array}$} & \multicolumn{3}{|c|}{ Treatments } & \multirow{2}{*}{ Means } \\
\cline { 2 - 5 } & $\mathbf{T}_{0}$ & $\mathbf{T}_{1}$ & $\mathbf{T}_{\mathbf{2}}$ & \\
\hline 0 & $71.23 \pm 2.42$ & $91.30 \pm 3.10$ & $115.08 \pm 3.91$ & $92.54 \pm 3.15^{\mathrm{a}}$ \\
\hline 15 & $69.78 \pm 2.23$ & $88.94 \pm 2.85$ & $114.22 \pm 3.66$ & $90.98 \pm 2.1^{\mathrm{ab}}$ \\
\hline 30 & $68.04 \pm 2.04$ & $86.53 \pm 2.60$ & $112.95 \pm 3.39$ & $89.17 \pm 2.68^{\mathrm{b}}$ \\
\hline 45 & $65.70 \pm 2.50$ & $85.06 \pm 3.23$ & $110.54 \pm 4.20$ & $87.10 \pm 3.31^{\mathrm{c}}$ \\
\hline 60 & $562.51 \pm 2.25$ & $85.06 \pm 3.23$ & $108.6 \pm 3.91$ & $84.97 \pm 3.06^{\mathrm{d}}$ \\
\hline Means & $67.45 \pm 2.29^{\mathrm{c}}$ & $87.12 \pm 2.96^{\mathrm{b}}$ & $112.28 \pm 3.81^{\mathrm{a}}$ & - \\
\hline $\mathrm{T}_{0}=$ (control bars) & & & \\
\hline $\mathrm{T}_{1}=$ (bars containing 3\% ginger CSE) \\
$\mathrm{T}_{2}=$ (bars containing $0.3 \%$ ginger SFE) \\
\hline
\end{tabular}

Table 2: Effect of treatments and storage on TPC (mg GAE/100 g) of bars.

\begin{tabular}{|c|c|c|c|c|}
\hline \multirow{2}{*}{$\begin{array}{c}\text { Storage } \\
\text { intervals (days) }\end{array}$} & \multicolumn{3}{|c|}{ Treatments } & Means \\
\cline { 2 - 5 } & $\mathbf{T}_{0}$ & $\mathbf{T}_{1}$ & $\mathbf{T}_{2}$ & \\
\hline 0 & $7.61 \pm 0.26$ & $15.92 \pm 0.54$ & $29.38 \pm 1.00$ & $17.64 \pm 0.60^{\mathrm{c}}$ \\
\hline 15 & $7.98 \pm 0.26$ & $16.19 \pm 0.52$ & $30.57 \pm 0.98$ & $18.25 \pm 0.58^{\mathrm{b}}$ \\
\hline 30 & $8.24 \pm 0.25$ & $16.44 \pm 0.49$ & $30.86 \pm 0.93$ & $18.51 \pm 0.56^{\mathrm{b}}$ \\
\hline 45 & $8.59 \pm 0.33$ & $17.70 \pm 0.67$ & $31.21 \pm 1.19$ & $19.17 \pm 0.73^{\mathrm{a}}$ \\
\hline 60 & $8.98 \pm 0.32$ & $18.13 \pm 0.65$ & $31.56 \pm 1.14$ & $19.56 \pm 0.70^{\mathrm{a}}$ \\
\hline Means & $8.28 \pm 0.28^{\mathrm{c}}$ & $16.88 \pm 0.58^{\mathrm{b}}$ & $30.72 \pm 1.05^{\mathrm{a}}$ & - \\
\hline $\mathrm{T}_{0}=$ (control bars) & & & \\
$\mathrm{T}_{1}^{=}=$(bars containing 3\% ginger CSE) & & \\
\hline $\mathrm{T}_{2}=$ (bars containing $0.3 \%$ ginger SFE) & \\
\hline
\end{tabular}

Table 3: Effect of treatments and storage on DPPH (\%) of bars.

\begin{tabular}{|c|c|c|c|c|}
\hline $\begin{array}{c}\text { Storage } \\
\text { intervals (days) }\end{array}$ & $\mathbf{T}_{\mathbf{0}}$ & $\mathbf{T}_{\mathbf{1}}$ & Means \\
\cline { 2 - 5 } & $12.39 \pm 0.42$ & $19.52 \pm 0.66$ & $32.43 \pm 1.10$ & $21.45 \pm 0.73^{\mathrm{c}}$ \\
\hline 0 & $12.81 \pm 0.41$ & $20.35 \pm 0.65$ & $32.97 \pm 1.06$ & $22.04 \pm 0.71^{\mathrm{b}}$ \\
\hline 15 & $13.28 \pm 0.40$ & $20.93 \pm 0.63$ & $33.65 \pm 1.01$ & $22.62 \pm 0.68^{\mathrm{b}}$ \\
\hline 30 & $13.76 \pm 0.52$ & $21.48 \pm 0.82$ & $34.12 \pm 1.30$ & $23.12 \pm 0.88^{\mathrm{a}}$ \\
\hline 45 & $14.1 \pm 0.51$ & $21.73 \pm 0.78$ & $34.86 \pm 1.25$ & $23.56 \pm 0.85^{\mathrm{a}}$ \\
\hline 60 & $13.27 \pm 0.45^{\mathrm{c}}$ & $20.80 \pm 0.71^{\mathrm{b}}$ & $33.61 \pm 1.14^{\mathrm{a}}$ & - \\
\hline Means & & & \\
\hline $\mathrm{T}_{0}=$ (control bars) \\
$\mathrm{T}_{1}=$ (bars containing 3\% ginger CSE) \\
$\mathrm{T}_{2}=$ (bars containing $0.3 \%$ ginger SFE) & & \\
\hline
\end{tabular}

Table 4: Effect of treatments and storage on antioxidant activity (\%) of bars.

DPPH: It is mostly used to assess the antioxidant potential that valued the antioxidant indices through free radical scavenging. Means for DPPH Table 3 demonstrated that free radical scavenging activity of $\mathrm{T}_{2}$ was maximum $30.72 \pm 1.05 \%$ followed by $\mathrm{T}_{1}$ and $\mathrm{T}_{0} 16.88 \pm 0.58$ and $8.28 \pm 0.28 \%$ respectively. Throughout storage interval the DPPH assay increased from $17.64 \pm 0.60$ to $19.56 \pm 0.70 \%$ whilst, maximum increase was observed in bars prepared by ginger supercritical extract ranging from $29.38 \pm 1.00$ to $31.56 \pm 1.14 \%$.

Antioxidant activity (AA): Mean antioxidant potential Table 4 regarding three treatments i.e. $\mathrm{T}_{0}$ (control), $\mathrm{T}_{1}(3 \%$ conventional ginger extract) and $\mathrm{T}_{2}(0.3 \%$ supercritical ginger extract $)$ has revealed maximum activity $(33.61 \pm 1.14 \%)$ was observed in $\mathrm{T}_{2}$ followed by $\mathrm{T}_{1}$ $(20.80 \pm 0.71)$ and $\mathrm{T}_{0}(13.27 \pm 0.45 \%)$. In the same way, storage factor has also influenced $B$ - carotene bleaching rate of each treatment that was highest at $60^{\text {th }}$ day $23.56 \pm 0.85 \%$ and lowest on first day i.e. 21.45 $\pm 0.73 \%$.

\section{Ferric Reducing Antioxidant Potential (FRAP)}

Results Table 5 have illustrated that $\mathrm{T}_{2}$ extract has maximum ferric reducing power $48.81 \pm 1.66$ that was low in $\mathrm{T}_{1} 35.60 \pm 1.21 \mu$ mole trolox equivalents/g ginger bar and $22.15 \pm 0.75$ in control bars. In the same way, significant effect was noted in storage time factor for each 
treatment that was higher $36.34 \pm 1.24$ at 0 day while lower $34.64 \pm 1.25$ $\mu$ mole trolox equivalents/g bar at $60^{\text {th }}$ day.

\section{ABTS assay}

From means Table 6, it was observed that maximum ABTS value was recorded in $\mathrm{T}_{2} 19.05 \pm 0.65$ followed by $\mathrm{T}_{1} 11.29 \pm 0.38$ and lowest was in control $5.94 \pm 0.20 \mu \mathrm{mol}$ trolox equivalents/g. Furthermore, it was also predicted as function of storage duration that maximum ABTS value $12.51 \pm 0.43 \mu \mathrm{mol}$ trolox equivalents/g was measured for ginger bar extract at 0 day while at $60^{\text {th }}$ day it was lowest $11.65 \pm 0.42$ $\mu \mathrm{mol}$ trolox equivalents/g.

\section{Metal chelating potential}

Values for effect of solvent and time Table 7 have shown highest chelating potential in $\mathrm{T}_{2} 21.22 \pm 0.72 \%$ followed by $17.88 \pm 0.61 \%$ in $\mathrm{T}_{1}$ and $16.41 \pm 0.56 \%$ in $\mathrm{T}_{0}$. Storage time also effected chelating potential as maximum amount $19.36 \pm 0.70 \%$ was observed at $60^{\text {th }}$ day while minimum $17.66 \pm 0.60 \%$ at 0 day.

\section{Antioxidant potential}

The results of current research were in harmony with the findings of Abdel-Samie [14] with his colleagues evaluated the effect of ginger as antioxidant on the dough mixing properties and quality of cookies

\begin{tabular}{|c|c|c|c|c|}
\hline $\begin{array}{c}\text { Storage } \\
\text { intervals (days) }\end{array}$ & $\mathbf{T}_{0}$ & $\mathbf{T}_{1}$ & \multirow{2}{*}{ Means } \\
\hline 0 & $23.05 \pm 0.78$ & $36.20 \pm 1.23$ & $49.76 \pm 1.69$ & $36.34 \pm 1.24^{\mathrm{c}}$ \\
\hline 15 & $22.76 \pm 0.73$ & $36.04 \pm 1.15$ & $49.24 \pm 1.58$ & $36.01 \pm 1.15^{\mathrm{c}}$ \\
\hline 30 & $22.18 \pm 0.67$ & $35.73 \pm 1.07$ & $48.83 \pm 1.46$ & $35.58 \pm 1.07^{\mathrm{b}}$ \\
\hline 45 & $21.63 \pm 0.82$ & $35.19 \pm 1.34$ & $48.31 \pm 1.84$ & $35.04 \pm 1.33^{\mathrm{b}}$ \\
\hline 60 & $21.14 \pm 0.76$ & $34.86 \pm 1.25$ & $47.92 \pm 1.73$ & $34.64 \pm 1.25^{\mathrm{a}}$ \\
\hline Means & $22.15 \pm 0.75^{\mathrm{c}}$ & $35.60 \pm 1.21^{\mathrm{b}}$ & $48.81 \pm 1.66^{\mathrm{a}}$ & - \\
\hline $\mathrm{T}_{0}=$ (control bars) \\
$\mathrm{T}_{1}=$ (bars containing 3\% ginger CSE) & & \\
$\mathrm{T}_{2}=$ (bars containing $0.3 \%$ ginger SFE) & & \\
\hline
\end{tabular}

Table 5: Effect of treatments and storage on FRAP ( $\mu$ mole TE/g) of bars.

\begin{tabular}{|c|c|c|c|c|}
\hline \multirow{2}{*}{$\begin{array}{c}\text { Storage } \\
\text { intervals (days) }\end{array}$} & $\mathbf{T}_{0}$ & $\mathbf{T}_{1}$ & Means \\
\cline { 2 - 5 } & $6.37 \pm 0.22$ & $11.72 \pm 0.40$ & $19.43 \pm 0.66$ & $12.51 \pm 0.43^{\mathrm{b}}$ \\
\hline 0 & $6.14 \pm 0.20$ & $11.59 \pm 0.37$ & $19.26 \pm 0.62$ & $12.33 \pm 0.39^{\mathrm{b}}$ \\
\hline 15 & $5.96 \pm 0.18$ & $11.26 \pm 0.34$ & $19.07 \pm 0.57$ & $12.10 \pm 0.36^{\mathrm{b}}$ \\
\hline 30 & $5.72 \pm 0.22$ & $11.03 \pm 0.42$ & $18.85 \pm 0.72$ & $11.87 \pm 0.45^{\mathrm{a}}$ \\
\hline 45 & $5.49 \pm 0.20$ & $10.85 \pm 0.39$ & $18.62 \pm 0.67$ & $11.65 \pm 0.42^{\mathrm{a}}$ \\
\hline 60 & $5.94 \pm 0.20^{\mathrm{c}}$ & $11.29 \pm 0.38^{\mathrm{b}}$ & $19.05 \pm 0.65^{\mathrm{a}}$ & - \\
\hline Means & & & \\
\hline $\mathrm{T}_{0}=$ (control bars) \\
$\mathrm{T}_{1}=$ (bars containing $3 \%$ ginger CSE) \\
$\mathrm{T}_{2}=$ (bars containing $0.3 \%$ ginger SFE)
\end{tabular}

Table 6: Effect of treatments and storage on ABTS ( $\mu$ mole TE/g) of bars.

\begin{tabular}{|c|c|c|c|c|}
\hline $\begin{array}{c}\text { Storage } \\
\text { intervals (days) }\end{array}$ & \multicolumn{3}{|c|}{ Treatments } & Means \\
\cline { 2 - 5 } & $\mathbf{T}_{0}$ & $\mathbf{T}_{1}$ & $\mathbf{T}_{2}$ & \\
\hline 0 & $15.37 \pm 0.52$ & $17.06 \pm 0.58$ & $20.54 \pm 0.70$ & $17.66 \pm 0.60^{\mathrm{c}}$ \\
\hline 15 & $15.94 \pm 0.51$ & $17.53 \pm 0.56$ & $20.8 \pm 0.67$ & $18.09 \pm 0.58^{\mathrm{b}}$ \\
\hline 30 & $16.45 \pm 0.49$ & $17.92 \pm 0.54$ & $21.18 \pm 0.64$ & $18.52 \pm 0.56^{\mathrm{b}}$ \\
\hline 45 & $16.82 \pm 0.64$ & $18.28 \pm 0.69$ & $21.64 \pm 0.82$ & $18.91 \pm 0.72^{\mathrm{ab}}$ \\
\hline 60 & $17.49 \pm 0.63$ & $18.61 \pm 0.67$ & $21.97 \pm 0.79$ & $19.36 \pm 0.70^{\mathrm{a}}$ \\
\hline Means & $16.41 \pm 0.56^{\mathrm{c}}$ & $17.88 \pm 0.61^{\mathrm{b}}$ & $21.23 \pm 0.72^{\mathrm{a}}$ & - \\
\hline $\mathrm{T}_{0}=$ (control bars) & & & \\
$\mathrm{T}_{1}=$ (bars containing $3 \%$ ginger CSE) \\
$\mathrm{T}_{2}=$ (bars containing $0.3 \%$ ginger SFE)
\end{tabular}

Table 7: Effect of treatments and storage on metal chelating potential (\%) of bars. and concluded that the total phenolic content of control cookies that were prepared by wheat flour alone were $78.5 \pm 1.1 \mathrm{mg} \mathrm{GAE} / 100 \mathrm{~g}$ of cookies that increased from $90.8 \pm 0.8$ to $109.8 \pm 2.7 \mathrm{mg} \mathrm{GAE} / 100 \mathrm{~g}$ of cookies by the gradually supplementation of ginger. Similarly, the antioxidant assay of ginger based cookies increased from $45.8 \pm 1.8$ to $64.6 \pm 1.0 \%$ by increasing the concentration of ginger that was $41.0 \pm$ $0.6 \%$ in control cookies.

Furthermore, Ashoush and Gadallah [15] prepared wheat flour biscuits ad concluded that the total phenolic contents on wheat flour were $1.59 \pm 0.05 \mathrm{mg} \mathrm{GAE} / \mathrm{g}$ of wheat flour biscuit that increased to 7.08 $\pm 0.07 \mathrm{mg} \mathrm{GAE} / \mathrm{g}$ by the addition of mango kernel powder as well as the DPPH assay of control wheat flour biscuits were $26.13 \pm 0.05 \%$ that increased to $91.57 \pm 0.11 \%$ by the enrichment of mango kernel powder. At the same moment, Zhu et al. [18] assessed the antioxidant potential of defatted wheat germ and resulted that the total phenolic content in wheat germ was $14.63 \pm 0.04 \mathrm{mg} \mathrm{GAE} / \mathrm{g}$ and DPPH assay was $75 \%$. For ABTS radical scavenging the value was $9.37 \pm 0.05 \mathrm{mg} / \mathrm{mL}$ as $\mathrm{IC}_{50} \beta$ carotene based antioxidant activity was $35.90 \%$ and for metal chelating potential the value of wheat germ was $25.7 \%$.

Additionally, an alternative group of researchers, Haase et al. [7] evaluated the ABTS and FRAP assay of wheat flour biscuits and clinched that after baking the ABTS assay of wheat flour based biscuits were $7.12 \pm 2.06$ to $7.68 \pm 1.91 \mathrm{mmol} \mathrm{TE} / \mathrm{kg}$ wheat flour though for FRAP assay the value was $3.10 \pm 0.98$ to $3.84 \pm 1.01 \mathrm{mmol} \mathrm{TE} / \mathrm{kg}$ wheat flour that varied by changing the baking temperature from $210^{\circ} \mathrm{C}$ to $240^{\circ} \mathrm{C}$. Moreover, Ahmad et al. [19] who prepared tiger nut enriched biscuits and assessed for nutritional and sensory aspects. They concluded that control biscuits without tiger nut supplementation have the total phenolic content of $2.11 \mathrm{mg} / \mathrm{g}$ of wheat flour and DPPH assay of $6.51 \%$ that gradually increased by the supplementation of tiger nut flour.

Another group of scientist Sharma and Gujral [13] prepared the wheat chapatties by the addition of barely flour and concluded that total phenolic content of wheat flour based chapatties were 2062 $\pm 36 \mu \mathrm{g} / \mathrm{g}$ in flour which increased by the incorporation of barely flour but decreased during baking (2016 $\pm 22 \mu \mathrm{g} / \mathrm{g}$ of chapatti) due to the decomposition of molecules at higher temperature beyond to $80^{\circ} \mathrm{C}$. Similarly, the antioxidant of wheat chapatties was $16.1 \pm 1.1 \%$ in the start that increased up to $30.6 \pm 0.40 \%$ during storage. During the processing of baking the antioxidant activity of baked products increased as compared to flour due to the maillard reaction that takes place in the availability of sugars and proteins. Some dark compounds normally brown colored are produced due to the thermal processing of baked products. These melanoidins (brown pigments) are briefly known to possess antioxidant properties [14]. Likewise, they determined the metal chelating power of wheat chapatties that was $27.4 \pm 0.5 \%$ and increased to $30.9 \pm 1.0 \%$ during baking and storage. In the meanwhile, they observed reducing power of wheat flour chapatties that was 29.1 $\pm 1.2 \mu$ mole ascorbic acid at the start and decreased slightly during storage.

Recently, Parn et al. [12] evaluated the antioxidant potential of wheat based fruit bars by utilizing date paste and concluded that the total phenolic content of bar ranges in $240.33 \pm 6.35$ to $224.33 \pm 1.15$ mg GAE/100 g although, the DPPH scavenging varied from $30.69 \pm$ 1.06 to $32.75 \pm 0.46$.

\section{Sensory evaluation of bars}

For sensory evaluation, bars were ranked using 9 point hedonic 
scale for their color, flavor, taste, crispiness and overall acceptability. Color being the most important character is the key of success of any product. If color does not affect then consumer would not like to even taste it. Means color marks for outcome of treatment has Figure 3 elucidated non-significant effect on color of bars; maximum $7.27 \pm$ 0.25 were assigned to $\mathrm{T}_{1}$ ( $3 \%$ ginger extract) followed by $\mathrm{T}_{0}(7.26 \pm$ $0.25)$ while minimum $7.23 \pm 0.25$ to $\mathrm{T}_{2}\left(0.3 \%\right.$ ginger nutraceutical $\left.{ }_{\mathrm{SFE}}\right)$. Color scores for bars significantly decreased as a function of storage from $7.43 \pm 0.25$ to $7.07 \pm 0.25$ during sixty days. It is obvious from the Figure 3 that the color was approximately same for all the treatments and hormonally the score of color decreased with time. Flavor is one of the characteristics which make product liked or disliked by the consumers. The flavor showed various results for treatments as well as storage intervals. It is obvious from the Figure 3 that $\mathrm{T}_{2}$ got higher marks for flavor $7.33 \pm 0.25$ in contrast to $\mathrm{T}_{1}(7.05 \pm 0.24)$ and $\mathrm{T}_{0}(6.66$ \pm 0.23 ) as ginger extracts in $\mathrm{T}_{1}$ and $\mathrm{T}_{2}$ caused pleasant flavor in bars. Figure 3 showed that the flavor of supercritical extract based bars got maximum marks among all the treatments followed by conventional extract based and control bars. Similarly, storage study has revealed that flavor of bars also changed significantly ranging from $7.27 \pm 0.25$ to $6.75 \pm 0.24$. Values for taste (Figure 3) showed that maximum score for taste was assigned to $\mathrm{T}_{2}(7.29 \pm 0.25)$ while minimum to $\mathrm{T}_{0}(6.97$ $\pm 0.24)$. Likewise, storage also decreased the taste marks from $7.38 \pm$ 0.25 to $6.95 \pm 0.25$. Crispiness specifies the crusty expertise of the food products. Same as the flavor and taste of nutraceutical ${ }_{\mathrm{SFE}}$ extract based bars was best from all three treatments as depicted by Figure 3. For bars crispiness Figure 4, maximum scores $7.41 \pm 0.25$ was noted for $T_{2}$ while minimum for $\mathrm{T}_{0}$ and $\mathrm{T}_{1} 7.25 \pm 0.25$ and $7.15 \pm 0.24$, correspondingly. Storage intervals also showed significant reduction from $7.42 \pm 0.25$ to $6.98 \pm 0.25$ in bars crispiness. Figure 4 proved that the control bars have good crispiness as compared to nutraceutical based bars. In view of the overall acceptability (Figure 4), $\mathrm{T}_{2}$ was considered best with allocated marks $7.34 \pm 0.25$, whereas $\mathrm{T}_{0}$ at the lower level with marks $7.04 \pm 0.24$. Overall acceptability also decreased with time from $7.47 \pm$ 0.25 to $6.98 \pm 0.25$ during sixty days storage of bars however remained highest for $\mathrm{T}_{2}$. Making an allowance for hedonic scale response, Figure 4 concluded that the bars containing $0.3 \%$ ginger supercritical extract were rated higher marks.

The results of current research work were in accordance to the finding of Abdel-Samie et al. [14] who observed the sensory profile of ginger based cookies. They concluded that the appearance color score of control cookies was $8.0 \pm 1.21$ that changed from $8.0 \pm 0.9$ to 7.5 \pm 1.1 by the addition of ginger. Similarly the texture of ginger based cookies was marked as $7.3 \pm 1.3$ to $6.9 \pm 1.1$ however it was $7.4 \pm 1.7$

\section{Color, Flavor, Taste in Sensory Attributes}

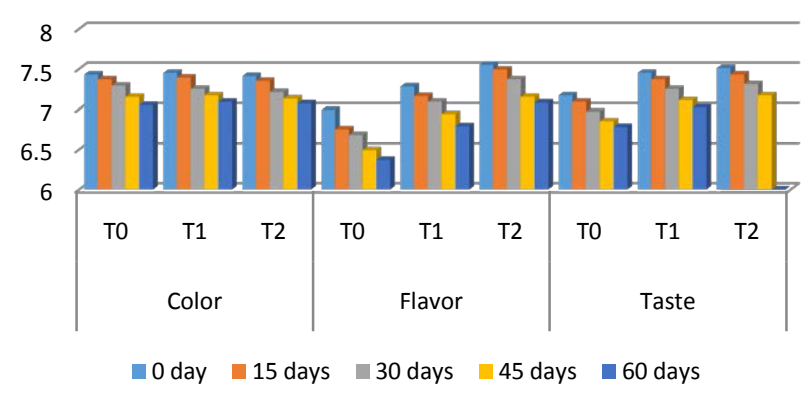

Figure 3: Color, flavor and taste scores of ginger bars.

\section{Crispiness and Overall acceptability}

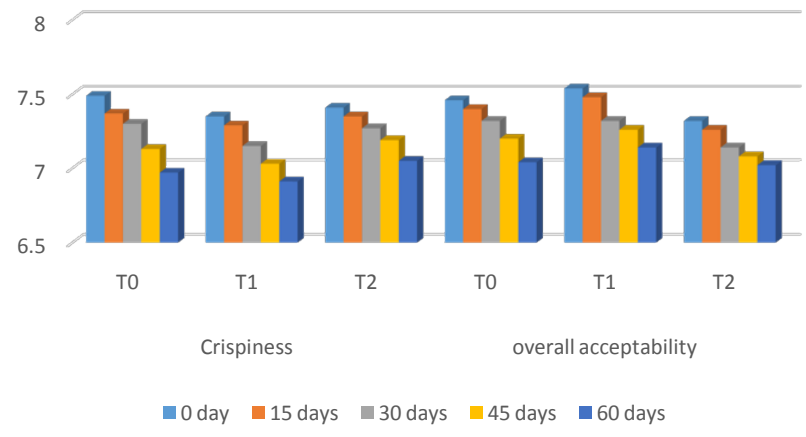

Figure 4: Crispiness and overall acceptability of ginger bars.

for control cookies. Furthermore, for the flavor grades were $7.5 \pm 1.4$ for control and $7.0 \pm 1.7$ to $6.4 \pm 1.4$ after the augmentation of ginger powder. Nonetheless, for overall acceptability best count was $8.1 \pm 0.8$ to $7.0 \pm 1.5$ for ginger cookies that was $7.4 \pm 1.4$ for control cookies.

Similarly, Oluwamukomi et al. [20] prepared wheat-cassava composite biscuits by the addition of soy flour. In their research work they concluded that the crispiness of wheat flour biscuits was marked as 8.0 while taste, aroma, shape, color and overall acceptability was scored as 8.0, 7.5, 6.0, 7.0 and 8.5 correspondingly.

\section{Conclusion}

During research work, two types of nutraceutical bars were prepared after supplementing with ginger enriched fractions against control. In the case of bars the $\mathrm{T}_{1}$ contained $3 \%$ ginger nutraceutical and $\mathrm{T}_{2}$ supplemented with $0.3 \%$ ginger supercritical extract. The treatments and storage exhibited significant variations in color tonality and texture that decreased from $61.02 \pm 2.07$ at 0 day to $56.80 \pm 2.04$ at $60^{\text {th }}$ day for $L^{*}, 7.75 \pm 0.26$ to $6.15 \pm 0.22$ for $\mathrm{a}^{*}$ however the values of $\mathrm{b}^{*}$, chroma and hue increased during storage from $34.65 \pm 1.18$ to 36.44 \pm 1.31 for $b^{*}, 35.51 \pm 1.21$ to $36.96 \pm 1.33$ for chroma and for hue the value was $77.34 \pm 2.63$ to $80.36 \pm 2.89$. Among antioxidant perspectives, $\mathrm{T}_{2}$ Showed maximum values for all tests such as TPC $(112.28 \pm 3.81 \mathrm{mg}$ GAE/100g), DPPH (30.72 $\pm 1.05 \%)$, antioxidant activity $(33.61 \pm 1.14)$, FRAP $(48.81 \pm 1.66 \mu$ mole TE/g), ABTS $(19.05 \pm 0.65 \mu$ mole TE/g) and metal chelating $(21.22 \pm 0.72 \%)$. $\mathrm{T}_{2}$ was followed by $\mathrm{T}_{1}$ with values $87.12 \pm 2.96 \mathrm{mg} \mathrm{GAE} / 100 \mathrm{~g}$ TPC, $16.88 \pm 0.58 \% \mathrm{DPPH}, 20.80 \pm 0.71 \%$ antioxidant activity, $35.60 \pm 1.21 \mu$ mole TE/g FRAP, $11.29 \pm 0.38 \mu$ mole TE/g ABTS and $11.29 \pm 0.38 \%$ for metal chelating. During storage the antioxidant potential decreased from $92.54 \pm 3.15$ to $84.97 \pm 3.06$ $\mathrm{mg} \mathrm{GAE} / 100 \mathrm{~g}$ in TPC, $36.34 \pm 1.24$ to $34.64 \pm 1.25 \mu$ mole TE/g for FRAP and $12.51 \pm 0.43$ to $11.65 \pm 0 . \mu$ mole TE/g for ABTS although, in DPPH it increased from $17.64 \pm 0.60$ to $19.56 \pm 0.70 \%, 21.45 \pm 0.73$ to $23.56 \pm 0.86 \%$ antioxidant activity and metal chelating potential increased from $17.66 \pm 0.60$ to $19.36 \pm 0.70 \pm$. Hedonic response was also assessed using 9-point hedonic scale for the estimation of color, flavor, crispiness, taste and overall acceptability of ginger bars. The maximum scores for color was $7.27 \pm 0.25\left(\mathrm{~T}_{1}\right), 7.33 \pm 0.28\left(\mathrm{~T}_{2}\right)$ for flavor, $7.29 \pm 0.25$ for taste $\left(\mathrm{T}_{2}\right), 7.25 \pm 0.25$ for control and $7.34 \pm 0.25$ $\left(\mathrm{T}_{2}\right)$ for overall acceptability.

\section{Acknowledgement}

This work was carried out under Pak-US Science and Technology project for establishment of Functional and Nutraceutical Research Section at University of 
Citation: Tanweer S, Shehzad A, Sadiq Butt M, Shahid M (2016) Phytochemical Profiling of Conventional and Supercritical Ginger Extract Based Baked Bars. J Food Process Technol 7: 596. doi:10.4172/2157-7110.1000596

Agriculture, Faisalabad-Pakistan. The financial and technical assistance under the framework of this project is highly acknowledged.

\section{References}

1. Martirosyan DM (2011) Introduction to functional food science In: Functional foods and chronic diseases. Danik M, Martirosyan (eds), Food Science Publisher: Richardson Texas USA. Pp: 173-204.

2. Fischer UA, Dettmann, JS, Carle R, Kammerer DR (2011) Impact of processing and storage on the phenolic profiles and contents of pomegranate (Punica granatum L.) juices. Europ Food Res Technol 233: 797-816.

3. Jensen S, Oestdal H, Clausen MR, Andersen ML, Skibsted LH (2011) Oxidative stability of whole wheat bread during storage. LWT Food Sci Technol 44: 637-642.

4. Patil S, Valdramidis VP, Tiwari BK, Cullen PJ, Bourke P (2011) Quantitative assessment of the shelf life of ozonated juice. Europ. Food Res Technol: 469-477.

5. Zielinski H, Del Castillo MD, Przygodzka M, Ciesarova Z (2012) Changes in chemical composition and antioxidative properties of rye ginger cakes during their shelf life. Food Chem 135: 2965-2973.

6. Tuncel NB, Yilmaz N, Kocabiyik H, Uygur A (2014a) The effect of infrared stabilized rice bran substitution on physicochemical and sensory properties of pan bread: part I. J Cereal Sci 59: 155-161.

7. Haase NU, Grothe KH, Mattaus B, Vosmann K, Lindhauer MG (2012) Acrylamide formation and antioxidant level in biscuits related to recipe and baking. Food Add Contam A 29:1230-1238.

8. Ibrahim UK, Salleh RM, Maqsood-ul-haque SNS (2015) Bread towards functional food: An overview. Int J Food Eng 1: 39-43.

9. Sivam AS, Sun-waterhouse D, Siew YQ, Perera CO (2010) Properties of bread dough with added fiber polysaccharides and phenolic antioxidants: A review. J Food Sci 75: 163-174.

10. Malipatili NB, Manjunath S, Shruthi DP (2015) Evaluation of effect of aqueous extract of Zingiber officinale Roscoe (ginger) on acute and chronic inflammation in adult albino rats. Asian J Pharma Clin Res 8: 113-116.

11. Embuscado ME (2015) Spices and herbs: natural sources of antioxidants-a mini review. J Func Foods.

12. Parn OJ, Bhat R, Yeoh TK, Hassan AA (2015) Development of novel fruit bars by utilizing date paste. Food Biosci 9: 20-27.

13. Sharma P, Gujral HS (2014) Antioxidant potential of wheat flour chapattis as affected by incorporation of barely flour. LWT- Food Sci Technol 56: 118-123.

14. Abdel-samie MAS, Wan J, Haung W, Chung OK, Xu B, et al. (2014) Effects of cumin and ginger as antioxidants on dough mixing properties and cookie quality. Cereal Chem 87: 454-460.

15. Ashoush IS, Gadallah MGE (2011) Utilization of mango peels and seed kernels powders as source of phytochemicals in biscuits. World J Dairy Food Sci 6: $35-42$.

16. Sharma P, Gujral HS, Singh B (2012) Antioxidant activity of barley as affected by extrusion cooking. Food Chem 131: 1406-1413.

17. Pasqalone A, Bianco AM, Paradiso VM, Summo C, Gambactora G, et al (2014) Physico-chemical sensory and volatile profiles of biscuits enriched with grape marc extract. Food Res Int 65: 385-393.

18. Zhu KX, Lian CX, Guo XN, Peng W, Zhou HM, et al. (2011) Antioxidant activities and total phenolic contents of various extracts from defatted wheat germ. Food Chem 126: 1122-1126.

19. Ahmad ZS, Abozed SS, Nagum MS (2014) Nutritional value and sensory profile of gluten free tiger nut enriched biscuits. World J Dairy Food Sci 9: 127-134.

20. Oluwamukomi MO, Oluwalana IB, Akinbowale OF (2011) Physicochemical and sensory properties of wheat-cassava composite biscuit enriched with soy flour. African J Food Sci 5: 50-56. 